\title{
Meta-analysis of the expression of the mitosis-related gene Fam83D
}

\author{
LOKMAN VARISLI \\ Department of Biology, Faculty of Science, Harran University, Osmanbey Campus, Sanliurfa, Turkey
}

Received June 21, 2012; Accepted September 12, 2012

DOI: $10.3892 / \mathrm{ol} .2012 .925$

\begin{abstract}
The family with sequence similarity 83, member D (Fam83D) encodes a mitotic spindle-associated protein. Its knockdown results in shorter spindles that fail to organize a correct metaphase plate. In this study, we demonstrated that Fam83D is coexpressed with well-known mitotic genes. Pathway analysis results also showed that cell cycle- and mitosis-related pathways are enriched with Fam83D-coexpressed genes. Furthermore, Fam83D is differentially expressed in various types of cancers. The results presented in this study suggest that Fam83D may be an important molecule for mitotic progression and equal segregation of chromosomes. Since the molecules that are involved in these mechanisms are crucial for mitosis as well as carcinogenesis, Fam83D should be considered as a novel regulator of mitosis and a putative carcinogenesis-related gene.
\end{abstract}

\section{Introduction}

The family with sequence similarity 83, member D (Fam83D, also known as CHICA) is located on chromosome 20 of the human genome (1). Fam83D contains an uncharacterized DUF1669 domain in the $\mathrm{N}$ terminus. The members of this domain family are found in all eukaryotes and are composed of sequences derived from hypothetical eukaryotic proteins of unknown function. Some members of this domain family are noted as being potential phospholipases, but no evidence from literature or sequence analysis was found to support this (2). Fam83D was identified as a putative mitotic spindle component in a mass spectrometry study (3). Furthermore, another study revealed that although Fam83D is primarily found in the cytoplasm during interphase, during prophase it associates with spindle microtubules, on which it remains throughout metaphase and anaphase (4). The same article also revealed that Fam83D is an interaction partner of chromokinesin KID,

Correspondence to: Dr Lokman Varisli, Department of Biology, Faculty of Science, Harran University, Osmanbey Campus, Sanliurfa, Turkey

E-mail: lokmanv@gmail.com

Key words: Fam83D, Oncomine, coexpression, gene ontology, in silico which is required for the generation of polar ejection forces and chromosome congression, and has roles in organizing the metaphase plate (4).

As all the mitotic spindle-associated proteins are involved in the control and regulation of cell proliferation, as well as in carcinogenesis, we further investigated Fam83D using in silico tools. Our results revealed that Fam83D is coexpressed with important mitosis-related genes, including Aurora-A, Aurora-B, Plk-1, Plk-4, Cdc20, Cdk1, Nek2, Geminin and CENP family members. All these molecules are well-known genes that have crucial roles in different stages of mitosis, from equal segregation of chromosomes to production of daughter cells. Therefore, we speculate that Fam83D is involved in mitotic processes to regulate cell division. Moreover, our results also demonstrated that this gene is differentially expressed in various cancers in concordance with the previously mentioned coexpression partners.

This is the first study concerning the correlation between Fam83D and cancer. It is well-known that differentially expressed genes in cancers are candidates for diagnostic and prognostic approaches. Therefore, this article suggests that Fam83D is a strong candidate for prognostic and diagnostic approaches and should be investigated further.

\section{Materials and methods}

Meta-analysis of Fam83D. To understand the function of Fam83D, coexpression analysis was performed using the Oncomine database (http://oncomine.org) as previously described $(5,6)$, but with minor modifications. The threshold was adjusted to P-value <1E-4; fold-change, 2 and gene rank, top $1 \%$. Seventeen different arrays fulfilled these criteria (Table I) and the top 200 coexpressed genes were extracted and filtered to give one representative gene per study (removing duplicates and partial expressed sequence tags). These filtered gene lists were then compared to search for repeatedly coexpressed genes over multiple studies. The frequency cut-off was 6 studies ( $>30 \%$ of 17 studies). This generated a meta-analysis list for Fam83D. The web-based Database for Annotation, Visualization and Integrated Discovery (DAVID; http://david.abcc.ncifcrf.gov) was used to assess enriched gene ontology terms within the gene lists produced by the coexpression data analysis $(7,8)$. The results were corrected for multiple testing using the Benjamini and Hochberg false discovery rate (FDR) correction. 
Table I. Arrays used in coexpression analysis.

\begin{aligned} & \hline No. Array name \\ & \hline 1 Lingren Bladder \\ & 2 Lee Brain \\ & 3 Bittner Breast \\ & 4 Richardson Breast 2 \\ & 5 Meyniel Ovarian \\ & 6 Lu Breast \\ & 7 HAO Esophagus \\ & 8 Anglesio Ovarian \\ & 9 Bittner Multicancer \\ & 10 Janoueix-Lerosey Brain \\ & 11 Lee Brain 2 \\ & 12 Skrzypczak Colorectal 2 \\ & 13 Ma Breast2 \\ & 14 Giordano Adrenal 2 \\ & 15 Yang Renal \\ & 16 Loi Breast 3 \\ & 17 Bittner Thyroid \\ & \hline\end{aligned}

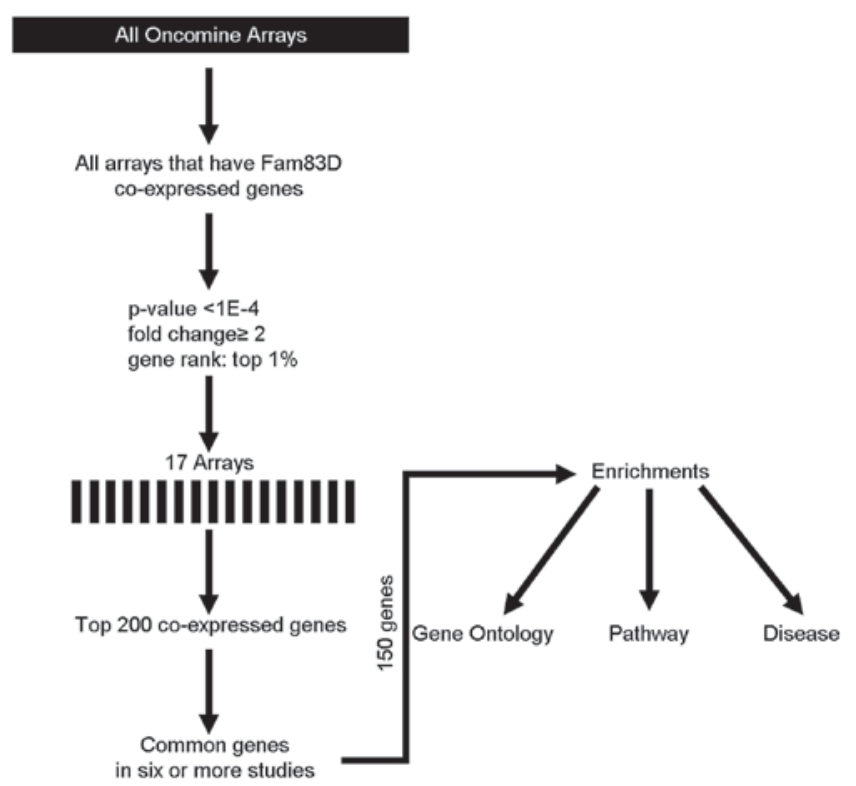

Figure 1. Methodological workflow of Fam83D meta-analysis.

Correlation between Fam $83 D$ and cancer. The oncomine cancer microarray database was used to study gene expression of Fam83D in various tumor types and in their normal control tissues. Only the gene transcriptome data from the same study, generated with the same methodology, were used. All gene expression data were log-transformed, median-centered per array, and standard deviation was normalized to one per array (9). Student's t-test was used for differential expression analysis, and only studies with P-value less than 1E-4 and fold-change greater than two were considered.
Table II. Fam83D-coexpressed genes.

\begin{tabular}{|c|c|c|}
\hline 1 ANLN & 51 DLGAP5 & 101 MYBL2 \\
\hline 2 APOBEC3B & 52 DSCC1 & $102 \mathrm{NCAPG}$ \\
\hline 3 ATAD2 & 53 DTL & 103 NCAPG2 \\
\hline 4 AURKA & 54 E2F7 & 104 NCAPH \\
\hline 5 AURKB & 55 E2F8 & 105 NDC80 \\
\hline 6 BIRC5 & 56 ЕСТ2 & 106 NEK2 \\
\hline 7 BUB1 & 57 ERCC6L & 107 NUF2 \\
\hline 8 BUB1B & 58 ESPL1 & 108 NUSAP1 \\
\hline 9 C11orf82 & 59 EXO1 & 109 IP5 \\
\hline 10 C15orf42 & 60 EZH2 & $110 \mathrm{PBK}$ \\
\hline 11 C16ORF75 & 61 FAM54A & 111 PHF19 \\
\hline 12 CASC5 & 62 FAM64A & 112 PLK1 \\
\hline 13 CCNA2 & 63 FANCI & 113 PLK4 \\
\hline 14 CCNB1 & 64 FBXO5 & 114 POLE2 \\
\hline $15 \mathrm{CCNB} 2$ & 65 FEN1 & 115 PRC1 \\
\hline $16 \mathrm{CDC} 20$ & 66 FOXM1 & 116 PTTG1 \\
\hline $17 \mathrm{CDC} 25 \mathrm{~A}$ & $67 \mathrm{GGH}$ & 117 RACGAP1 \\
\hline $18 \mathrm{CDC} 25 \mathrm{~B}$ & $68 \mathrm{GIN}$ & 118 RAD51 \\
\hline $19 \mathrm{CDC} 25 \mathrm{C}$ & 69 GINS2 S1 & 119 RAD54L \\
\hline $20 \mathrm{CDC} 45$ & 70 GINS4 & 120 RECQL4 \\
\hline 21 CDC6 & 71 GMNN & 121 RFC3 \\
\hline $22 \mathrm{CDC} 7$ & 72 GPSM2 & 122 RFC4 \\
\hline 23 CDCA2 & 73 GTSE1 & 123 RNASEH2A \\
\hline 24 CDCA3 & 74 HELLS & 124 RRM2 \\
\hline 25 CDCA5 & 75 HJURP & 125 SGOL2 \\
\hline 26 CDCA7 & 76 HMMR & 126 SHCBP1 \\
\hline 27 CDCA8 & 77 KIAA0101 & 127 SLC7A5 \\
\hline $28 \mathrm{CDK} 1$ & 78 KIF11 & $128 \mathrm{SMC} 4$ \\
\hline $29 \mathrm{CDKN} 3$ & 79 KIF14 & 129 SPAG5 \\
\hline 30 CDT1 & 80 KIF15 & 130 SPC24 \\
\hline 31 CENPA & 81 KIF18B & $131 \mathrm{SPC} 25$ \\
\hline 32 CENPE & 82 KIF20A & 132 STIL \\
\hline $33 \mathrm{CENPF}$ & 83 KIF23 & 133 TACC 3 \\
\hline 34 CENPI & 84 KIF2C & 134 TFRC \\
\hline 35 CENPJ & $85 \mathrm{KIF} 4 \mathrm{~A}$ & 135 TIMELESS \\
\hline 36 CENPK & 86 KIFC1 & 136 TK1 \\
\hline 37 CENPM & 87 KPNA2 & 137 TOP $2 A$ \\
\hline 38 CENPN & 88 LMNB1 & 138 TPX2 \\
\hline 39 CENPW & 89 MAD2L1 & 139 TRIM59 \\
\hline 40 CEP55 & 90 MASTL & 140 TRIP13 \\
\hline 41 CHEK 1 & 91 MCM10 & 141 TROAP \\
\hline 42 CKAP2 & $92 \mathrm{MCM} 2$ & 142 TTK \\
\hline 43 CKAP2L & $93 \mathrm{MCM} 4$ & 143 TYMS \\
\hline $44 \mathrm{CKS} 1 \mathrm{~B}$ & 94 MCM6 & 144 UBE2C \\
\hline $45 \mathrm{CKS} 2$ & 95 MCM7 & $145 \mathrm{UBE} 2 \mathrm{~S}$ \\
\hline 46 DBF4 & 96 MCM8 & 146 UBE2T \\
\hline 47 DEPDC1 & 97 MELK & 147 UHRF1 \\
\hline 48 DEPDC1B & 98 MKI67 & 148 WHSC 1 \\
\hline 49 DHFR & 99 MLF1IP & 149 ZNF367 \\
\hline 50 DIAPH3 & 100 MYBL1 & 150 ZWINT \\
\hline
\end{tabular}


Table III. Functional enrichment of Fam83D-coexpressed genes.

\begin{tabular}{|c|c|c|c|c|c|}
\hline Term & Count & $\%$ & P-value & Fold & FDR \\
\hline GO:0007049 - Cell cycle & 88 & 59.1 & $1.90 \mathrm{E}-74$ & 11.2 & $1.31 \mathrm{E}-71$ \\
\hline GO:0000279 - M phase & 65 & 43.6 & $9.23 \mathrm{E}-68$ & 19.5 & $3.19 \mathrm{E}-65$ \\
\hline GO:0022403 - Cell cycle phase & 69 & 46.3 & $3.78 \mathrm{E}-67$ & 16.5 & $8.71 \mathrm{E}-65$ \\
\hline GO:0022402 - Cell cycle process & 73 & 49 & $2.29 \mathrm{E}-63$ & 12.8 & $3.96 \mathrm{E}-61$ \\
\hline GO:0000278 - Mitotic cell cycle & 62 & 41.6 & $1.39 \mathrm{E}-59$ & 16.5 & $1.92 \mathrm{E}-57$ \\
\hline GO:0007067 - Mitosis & 53 & 35.6 & $7.11 \mathrm{E}-59$ & 23.8 & $8.19 \mathrm{E}-57$ \\
\hline GO:0000280 - Nuclear division & 53 & 35.6 & $7.11 \mathrm{E}-59$ & 23.8 & $8.19 \mathrm{E}-57$ \\
\hline GO:0000087 - M phase of mitotic cell cycle & 53 & 35.6 & $2.01 \mathrm{E}-58$ & 23.4 & $1.99 \mathrm{E}-56$ \\
\hline GO:0048285 - Organelle fission & 53 & 35.6 & $7.15 \mathrm{E}-58$ & 22.9 & $6.18 \mathrm{E}-56$ \\
\hline GO:0051301 - Cell division & 53 & 35.6 & $1.10 \mathrm{E}-51$ & 17.7 & $8.47 \mathrm{E}-50$ \\
\hline GO:0006260 - DNA replication & 31 & 20.8 & $8.29 \mathrm{E}-28$ & 16.1 & $5.73 \mathrm{E}-26$ \\
\hline GO:0007059 - Chromosome segregation & 22 & 14.8 & $1.82 \mathrm{E}-24$ & 26.8 & $1.14 \mathrm{E}-22$ \\
\hline GO:0006259 - DNA metabolic process & 40 & 26.8 & $3.13 \mathrm{E}-24$ & 7.81 & $1.80 \mathrm{E}-22$ \\
\hline GO:0051726 - Regulation of cell cycle & 33 & 22.1 & 7.82E-23 & 9.84 & 4.16E-21 \\
\hline GO:0007017 - Microtubule-based process & 29 & 19.5 & $1.31 \mathrm{E}-21$ & 11.3 & $6.46 \mathrm{E}-20$ \\
\hline GO:0007051 - Spindle organization & 15 & 10.1 & $6.83 \mathrm{E}-18$ & 32.9 & $3.15 \mathrm{E}-16$ \\
\hline GO:0000070 - Mitotic sister chromatid segregation & 14 & 9.4 & $1.12 \mathrm{E}-17$ & 38.4 & $4.82 \mathrm{E}-16$ \\
\hline GO:0000819 - Sister chromatid segregation & 14 & 9.4 & $1.71 \mathrm{E}-17$ & 37.4 & $6.93 \mathrm{E}-16$ \\
\hline GO:0007346 - Regulation of mitotic cell cycle & 21 & 14.1 & 3.98E-17 & 13.6 & $1.53 \mathrm{E}-15$ \\
\hline GO:0010564 - Regulation of cell cycle process & 19 & 12.8 & $5.90 \mathrm{E}-17$ & 16.5 & $4.00 \mathrm{E}-15$ \\
\hline GO:0000226 - Microtubule cytoskeleton organization & 20 & 13.4 & $3.60 \mathrm{E}-16$ & 13.4 & $1.15 \mathrm{E}-14$ \\
\hline GO:0000075 - Cell cycle checkpoint & 15 & 10.1 & $3.02 \mathrm{E}-13$ & 16.3 & $9.93 \mathrm{E}-12$ \\
\hline GO:0051276 - Chromosome organization & 27 & 18.1 & $1.98 \mathrm{E}-12$ & 5.5 & $6.22 \mathrm{E}-11$ \\
\hline GO:0007126 - Meiosis & 13 & 8.72 & $2.54 \mathrm{E}-10$ & 13.1 & $7.63 \mathrm{E}-09$ \\
\hline GO:0051327 - M phase of meiotic cell cycle & 13 & 8.72 & $2.54 \mathrm{E}-10$ & 13.1 & 7.63E-09 \\
\hline GO:0051321 - Meiotic cell cycle & 13 & 8.72 & $3.23 \mathrm{E}-10$ & 12.8 & $9.29 \mathrm{E}-09$ \\
\hline GO:0007093 - Mitotic cell cycle checkpoint & 10 & 6.71 & $3.39 \mathrm{E}-10$ & 23 & 9.37E-09 \\
\hline GO:0007010 - Cytoskeleton organization & 23 & 15.4 & $3.87 \mathrm{E}-10$ & 5.21 & 1.03E-08 \\
\hline GO:0051329 - Interphase of mitotic cell cycle & 13 & 8.72 & 4.58E-10 & 12.5 & $1.17 \mathrm{E}-08$ \\
\hline GO:0051325 - Interphase & 13 & 8.72 & $6.43 \mathrm{E}-10$ & 12.1 & $1.59 \mathrm{E}-08$ \\
\hline GO:0006974 - Response to DNA damage stimulus & 21 & 14.1 & $9.27 \mathrm{E}-10$ & 5.56 & $2.21 \mathrm{E}-08$ \\
\hline GO:0007088 - Regulation of mitosis & 10 & 6.71 & 4.08E-09 & 17.6 & $9.40 \mathrm{E}-08$ \\
\hline GO:0051783 - Regulation of nuclear division & 10 & 6.71 & 4.08E-09 & 17.6 & $9.40 \mathrm{E}-08$ \\
\hline GO:0006261 - DNA-dependent DNA replication & 10 & 6.71 & $5.64 \mathrm{E}-09$ & 17 & $1.26 \mathrm{E}-07$ \\
\hline GO:0008283 - Cell proliferation & 21 & 14.1 & 1.34E-08 & 4.76 & $2.89 \mathrm{E}-07$ \\
\hline GO:0048015 - Phosphoinositide-mediated signaling & 11 & 7.38 & $1.75 \mathrm{E}-08$ & 12.3 & $3.67 \mathrm{E}-07$ \\
\hline GO:0006323 - DNA packaging & 11 & 7.38 & $2.71 \mathrm{E}-07$ & 9.28 & $5.50 \mathrm{E}-06$ \\
\hline GO:0051640 - Organelle localization & 10 & 6.71 & $3.45 \mathrm{E}-07$ & 10.7 & $6.81 \mathrm{E}-06$ \\
\hline GO:0033554 - Cellular response to stress & 21 & 14.1 & $9.19 \mathrm{E}-07$ & 3.66 & $1.76 \mathrm{E}-05$ \\
\hline GO:0006281 - DNA repair & 15 & 10.1 & $1.01 \mathrm{E}-06$ & 5.22 & $1.88 \mathrm{E}-05$ \\
\hline GO:0007018 - Microtubule-based movement & 10 & 6.71 & $1.98 \mathrm{E}-06$ & 8.74 & $3.61 \mathrm{E}-05$ \\
\hline GO:0033043 - Regulation of organelle organization & 11 & 7.38 & $6.71 \mathrm{E}-05$ & 5.01 & 0.001188 \\
\hline
\end{tabular}

Fold, fold enhancement; FDR, false discovery rate.

\section{Results}

Fam83D is coexpressed with genes involved in mitosis. Using the Oncomine cancer microarray database Fam83D was searched for coexpressed genes. Fig. 1 indicates the meth- odological workflow of the meta-analysis and the selected multi-array studies for Fam83D. Following meta-analysis, 150 genes were found to be coexpressed in six or more studies (Table II). DAVID was used to perform gene ontology (GO) term enrichment analysis to obtain characteristics of the set 
Table IV. Pathway-based enrichment of Fam83D-coexpressed genes.

\begin{tabular}{|c|c|c|c|c|c|}
\hline Term & Count & $\%$ & P-value & Fold & FDR \\
\hline hsa04110: Cell cycle & 24 & 16.1 & $1.16 \mathrm{E}-25$ & 20.3 & $3.24 \mathrm{E}-24$ \\
\hline hsa03030: DNA replication & 9 & 6.04 & 7.12E-10 & 26.5 & 9.97E-09 \\
\hline hsa04114: Oocyte meiosis & 12 & 8.05 & 2.66E-09 & 11.6 & $2.48 \mathrm{E}-08$ \\
\hline hsa04914: Progesterone-mediated oocyte maturation & 10 & 6.71 & $5.97 \mathrm{E}-08$ & 12.3 & $4.18 \mathrm{E}-07$ \\
\hline hsa04115: p53 signaling pathway & 6 & 4.03 & $3.66 \mathrm{E}-04$ & 9.35 & 0.002048 \\
\hline
\end{tabular}

Fold, fold enrichment; FDR, false discovery rate.

Table V. Disease-based enrichment of Fam83D-coexpressed genes.

\begin{tabular}{|c|c|c|c|c|c|}
\hline Term & Count & $\%$ & P-value & Fold & FDR \\
\hline Breast cancer & 13 & 8.7 & $1.91 \mathrm{E}-06$ & 4.9 & $1.39 \mathrm{E}-04$ \\
\hline Colorectal cancer & 6 & 4.0 & 0.029838 & 3.2 & 0.669009 \\
\hline
\end{tabular}

Fold, fold enrichment; FDR, false discovery rate.

of significant genes from our meta-analyses. This analysis provides a list of gene functions, which are overrepresented in a gene set. Analysis of the 150 Fam83D-coexpressed genes with the DAVID functional annotation tool (GOTERM BP FAT) resulted in 181 GO categories (cut-off, $\mathrm{P}<0.05$; count $\geq 2$ and fold enrichment $>1.5$ ) (data not shown). To produce a more comprehensive and structured view of the annotation terms, a DAVID clustering analysis under high-stringency conditions was performed, resulting in 42 annotation clusters matching the statistical criteria $(\mathrm{P}<0.0001$, count $\geq 10$ and fold enrichment >1.5) (Table III). Subsequently, the aforementioned DAVID annotation tool was used for identification of putative KEGG pathways associated with Fam83D-coexpressed genes. Consequently, five pathways associated with the cell cycle, mitosis and related signaling pathways were significantly enriched with Fam83D-coexpressed genes $(\mathrm{P}<0.05$ and fold enrichment $>1.5$ ) (Table IV). In addition, DAVID was used for predicting putative diseases that linked with Fam83Dcoexpressed genes using the Genetic Association Database. The results revealed that breast and colorectal cancers were significantly enriched with these genes $(\mathrm{P}<0.05$ and fold enrichment $>1.5$ ) (Table V).

Fam83D is differentially expressed in various cancers. We investigated the expression of Fam83D in cancer using publicly available gene expression data from Oncomine (Table VI). Fam83D has been found to be upregulated in various tumors including in breast cancer compared to normal breast (10); in colorectal cancer compared to normal colon or rectum in three independent studies (11-13); in gastric cancer compared to gastric mucosa in two independent studies $(14,15)$; in hepatocellular carcinoma compared to normal liver in two independent studies $(16,17)$; in lung cancer compared to normal lung in two independent studies $(18,19)$ and in vulva intraepithelial neoplasia compared to normal vulva (20).
Table VI. Differential expression of Fam83D in cancer types compared to their normal counterparts, using the Oncomine cancer microarray database.

\begin{tabular}{lccc}
\hline Type of cancer & Overexpressed & Underexpressed & Ref. \\
\hline Breast & + & & $(10)$ \\
Cervical & + & $(20)$ \\
Colorectal & + & & $(11-13)$ \\
Esophageal & & + & $(22)$ \\
Gastric & + & & $(14,15)$ \\
Glioblastoma & & + & $(21)$ \\
Hepatocellular & + & & $(16,17)$ \\
Leukemia & & + & $(23)$ \\
Lung & + & & $(18,19)$ \\
\hline
\end{tabular}

Conversely, downregulation of Fam83D was found in glioblastoma compared to neural stem cells (21); in esophageal cancer compared to normal esophagus (22) and in leukemia compared to peripheral blood mononuclear cells (23).

\section{Discussion}

The main function of the cell cycle is to accurately duplicate the entire genome and segregate a copy of each chromosome precisely into two daughter cells. Maintenance of a correct chromosome number is essential for the survival of an organism. Errors in the cell division may lead to loss or gain of chromosomes and consequently to aneuploidy. In mitotically dividing cells, aneuploidy is a hallmark of cancer and many cancer cells are characterized by high rates of chromosomal 
instability (CIN). CIN leads to the persistent generation of new chromosomal variations, to tumor progression and to the development of more aggressive phenotypes (24). Centrosomes have important roles in equal segregation of chromosomes through the establishment of bipolar spindle formation during mitosis. Many studies have reported that centrosomelocated proteins are involved in the regulation of centrosome organization $(25,26)$. Moreover, it has been demonstrated that deregulation of the centrosome organization machinery is a clear source of centrosome amplification (27). There is a growing line of evidence to suggest that most solid tumors and many hematopoietic malignancies contain cells with centrosome abnormalities (28-30). For example, the centrosomal mitotic kinases Aurora-A, Plk-1, Plk-4 and Nek2 are all Fam83D-coexpressed genes (Table II), involved in multiple mitotic events. These range from centrosome maturation to centrosome separation, spindle formation and cytokinesis, and their deregulation has been linked to centrosome abnormalities and consequently carcinogenesis (31-35). Therefore, all centrosome and bipolar spindle-associated proteins are considered as putative cancer-related molecules. Santamaria et al have demonstrated that Fam83D localizes to the mitotic spindle, and Fam83D-depleted cells form shorter spindles and fail to organize a correct metaphase plate (4). In this study, we showed that Fam83D is coexpressed with many centrosome-located and mitosis-related genes, which are involved in normal cell cycle progression as well as in carcinogenesis. Notably, the majority of the coexpressed genes were key molecules for entry into mitosis, mitotic progression and cytokinesis. All these processes are related to centrosome organization and important to the faithful segregation of chromosomes. Therefore, we suggested that Fam83D may be involved in equal segregation of chromosomes during mitosis. In concordance with this hypothesis, our results also revealed that Fam83D is differentially expressed in some cancers that are directly linked to centrosome abnormalities, such as bladder (36), breast (37), lung (38), colorectal (30) or hepatocellular (39) carcinomas and leukemia (40).

In conclusion, we performed a meta-analysis for Fam83D using in silico approaches. Our results revealed that this molecule may be important for centrosome organization, mitotic processes and also in carcinogenesis. In silico studies support wet-lab approaches to finding new diagnostic, therapeutic and prognostic factors by using various tools, software and large-scale databases. However, the results of in silico studies generally need confirmation by lab experiments. Therefore, further investigation of the results presented in this study by experimental approaches may increase our understanding of centrosome organization, mitosis and carcinogenesis.

\section{References}

1. Deloukas P, Matthews LH, Ashurst J, et al: The DNA sequence and comparative analysis of human chromosome 20. Nature 414: 865-871,2001.

2. Finn RD, Mistry J, Tate J, et al: The Pfam protein families database. Nucleic Acids Res 38: D211-D222, 2010.

3. Sauer G, Korner R, Hanisch A, Ries A, Nigg EA and Sillje HH: Proteome analysis of the human mitotic spindle. Mol Cell Proteomics 4: 35-43, 2005.

4. Santamaria A, Nagel S, Sillje HH and Nigg EA: The spindle protein CHICA mediates localization of the chromokinesin Kid to the mitotic spindle. Curr Biol 18: 723-729, 2008.
5. Wilson BJ: Meta-analysis of SUMO1. BMC Res Notes 1: 60, 2008.

6. Wilson BJ and Giguere V: Meta-analysis of human cancer microarrays reveals GATA3 is integral to the estrogen receptor alpha pathway. Mol Cancer 7: 49, 2008.

7. Huang da W, Sherman BT and Lempicki RA: Systematic and integrative analysis of large gene lists using DAVID bioinformatics resources. Nat Protoc 4: 44-57, 2009.

8. Huang da W, Sherman BT and Lempicki RA: Bioinformatics enrichment tools: paths toward the comprehensive functional analysis of large gene lists. Nucleic Acids Res 37: 1-13, 2009.

9. Rhodes DR, Yu J, Shanker K, et al: ONCOMINE: a cancer microarray database and integrated data-mining platform. Neoplasia 6: 1-6, 2004.

10. Richardson AL, Wang ZC, De Nicolo A, et al: X chromosomal abnormalities in basal-like human breast cancer. Cancer Cell 9: 121-132, 2006.

11. Hong Y, Downey T, Eu KW, Koh PK and Cheah PY: A 'metastasis-prone' signature for early-stage mismatch-repair proficient sporadic colorectal cancer patients and its implications for possible therapeutics. Clin Exp Metastasis 27: 83-90, 2010.

12. Sabates-Bellver J, Van der Flier LG, de Palo M, et al: Transcriptome profile of human colorectal adenomas. Mol Cancer Res 5: 1263-1275, 2007.

13. Skrzypczak M, Goryca K, Rubel T, et al: Modeling oncogenic signaling in colon tumors by multidirectional analyses of microarray data directed for maximization of analytical reliability. PLoS One 5: e13091, 2010.

14. Chen X, Leung SY, Yuen ST, et al: Variation in gene expression patterns in human gastric cancers. Mol Biol Cell 14: 3208-3215, 2003.

15. D'Errico M, de Rinaldis E, Blasi MF, et al: Genome-wide expression profile of sporadic gastric cancers with microsatellite instability. Eur J Cancer 45: 461-469, 2009.

16. Chen X, Cheung ST, So S, et al: Gene expression patterns in human liver cancers. Mol Biol Cell 13: 1929-1939, 2002.

17. Wurmbach E, Chen YB, Khitrov G, et al: Genome-wide molecular profiles of $\mathrm{HCV}$-induced dysplasia and hepatocellular carcinoma. Hepatology 45: 938-947, 2007.

18. Garber ME, Troyanskaya OG, Schluens K, et al: Diversity of gene expression in adenocarcinoma of the lung. Proc Natl Acad Sci USA 98: 13784-13789, 2001.

19. Hou J, Aerts J, den Hamer B, et al: Gene expression-based classification of non-small cell lung carcinomas and survival prediction. PLoS One 5: e10312, 2010.

20. Santegoets LA, Seters M, Helmerhorst TJ, et al: HPV related VIN: highly proliferative and diminished responsiveness to extracellular signals. Int J Cancer 121: 759-766, 2007.

21. Lee J, Kotliarova S, Kotliarov Y, et al: Tumor stem cells derived from glioblastomas cultured in bFGF and EGF more closely mirror the phenotype and genotype of primary tumors than do serum-cultured cell lines. Cancer Cell 9: 391-403, 2006.

22. Kim SM, Park YY, Park ES, et al: Prognostic biomarkers for esophageal adenocarcinoma identified by analysis of tumor transcriptome. PLoS One 5: e15074, 2010.

23. Haferlach T, Kohlmann A, Wieczorek L, et al: Clinical utility of microarray-based gene expression profiling in the diagnosis and subclassification of leukemia: report from the International Microarray Innovations in Leukemia Study Group. J Clin Oncol 28: 2529-2537, 2010.

24. Loeb LA: A mutator phenotype in cancer. Cancer Res 61: 3230-3239, 2001

25. Cizmecioglu O, Arnold M, Bahtz R, et al: Cep152 acts as a scaffold for recruitment of Plk4 and CPAP to the centrosome. J Cell Biol 191: 731-739, 2010.

26. Cizmecioglu O, Warnke S, Arnold M, Duensing S and Hoffmann I: Plk-2 regulated centriole duplication is dependent on its localization to the centrioles and a functional polo-box domain. Cell Cycle 7: 3548-3555, 2008.

27. Zyss D and Gergely F: Centrosome function in cancer: guilty or innocent? Trends Cell Biol 19: 334-346, 2009.

28. Brinkley BR: Managing the centrosome numbers game: from chaos to stability in cancer cell division. Trends Cell Biol 11: 18-21,2001.

29. Carroll PE, Okuda M, Horn HF, et al: Centrosome hyperamplification in human cancer: chromosome instability induced by $\mathrm{p} 53$ mutation and/or Mdm2 overexpression. Oncogene 18: 1935-1944, 1999.

30. Pihan GA, Purohit A, Wallace J, et al: Centrosome defects and genetic instability in malignant tumors. Cancer Res 58: 3974-3985, 1998. 
31. Habedanck R, Stierhof YD, Wilkinson CJ and Nigg EA: The Polo kinase Plk-4 functions in centriole duplication. Nat Cell Biol 7: 1140-1146, 2005.

32. Hayward DG and Fry AM: Nek-2 kinase in chromosome instability and cancer. Cancer Lett 237: 155-166, 2006.

33. Lu LY, Wood JL, Ye L, et al: Aurora-A is essential for early embryonic development and tumor suppression. J Biol Chem 283: 31785-31790, 2008.

34. Wang XQ, Zhu YQ, Lui KS, Cai Q, Lu P and Poon RT: Aberrant Polo-like kinase 1-Cdc25A pathway in metastatic hepatocellular carcinoma. Clin Cancer Res 14: 6813-6820, 2008.

35. Lu LY, Wood JL, Minter-Dykhouse K, et al: Polo-like kinase 1 is essential for early embryonic development and tumor suppression. Mol Cell Biol 28: 6870-6876, 2008.

36. Yamamoto Y, Matsuyama H, Furuya T, et al: Centrosome hyperamplification predicts progression and tumor recurrence in bladder cancer. Clin Cancer Res 10: 6449-6455, 2004.
37. Lingle WL, Lutz WH, Ingle JN, Maihle NJ and Salisbury JL: Centrosome hypertrophy in human breast tumors: implications for genomic stability and cell polarity. Proc Natl Acad Sci USA 95: 2950-2955, 1998.

38. Jung CK, Jung JH, Lee KY, et al: Centrosome abnormalities in non-small cell lung cancer: correlations with DNA aneuploidy and expression of cell cycle regulatory proteins. Pathol Res Pract 203: 839-847, 2007

39. Nakajima T, Moriguchi M, Mitsumoto Y, et al: Centrosome aberration accompanied with p53 mutation can induce genetic instability in hepatocellular carcinoma. Mod Pathol 17: 722-727, 2004.

40. Giehl M, Fabarius A, Frank O, et al: Centrosome aberrations in chronic myeloid leukemia correlate with stage of disease and chromosomal instability. Leukemia 19: 1192-1197, 2005. 